\title{
Kajian Spiritualitas di Tempat Kerja pada Konteks Organisasi Bisnis
}

\author{
Leo Agung Manggala Yogatama ${ }^{1}$ \\ Fakultas Psikologi Universitas Atma Jaya Jakarta \\ Nilam Widyarini ${ }^{2}$ \\ Fakultas Psikologi Universitas Gunadarma Jakarta
}

\begin{abstract}
Spirituality at workplace is a new topic in organizational psychology. Spirituality at workplace is related to a construction that indicates an increase of quality performance. The purpose of this study was to find the factors forming the spiritual climate in Indonesian organizational context. The subjects were 417 employees of a media company. The method used in this study was exploratory factor analysis. The results indicated that there were two factors forming the spiritual climate in the workplace, namely vision and mission that motivated the employees and made them connected with their purposes at work, and the second factor was employees' deep concern of their lives. This study can be used as a practical guidance to establish a healthy working climate in organization.
\end{abstract}

Keywords: exploratory factor analysis, spirituality, spirituality at the workplace

Abstrak. Spiritualitas di tempat kerja merupakan topik baru dalam psikologi keorganisasian. Spiritualitas di tempat kerja berkaitan dengan konstruk yang menunjukkan peningkatan kualitas kinerja. Tujuan dari penelitian ini adalah untuk menemukan faktor-faktor yang membentuk iklim spiritual dalam konteks organisasi di Indonesia. Subjek penelitian ini adalah 417 karyawan sebuah perusahaan media. Metode dalam penelitian ini adalah analisis faktor eksploratori. Hasilnya menunjukkan bahwa ada dua faktor yang membentuk iklim spiritual di tempat kerja, yaitu Visi dan Misi yang membuat seseorang termotivasi dan merasakan tujuan di tempat kerja, dan faktor kedua adalah Kepedulian mendalam akan kehidupan karyawan. Penelitian ini dapat digunakan sebagai panduan praktis untuk membangun iklim kerja yang sehat pada organisasi.

Kata kunci: analisis faktor eksplorasi, spiritualitas, spiritualitas di tempat kerja

Organisasi dapat didefinisikan sebagai kumpulan orang yang ingin mencapai tujuan bersama. Pada dasarnya, organisasi digunakan sebagai alat serta wadah bagi orang-orang untuk berkumpul dan bekerja sama secara rasional dan sistematis. Rasional dan sistematis dapat dijelaskan dengan adanya kerja yang terencana,

\footnotetext{
${ }^{1}$ Korespondensi mengenai artikel ini dapat melalui: leoagung.my@gmail.com

2 Atau melalui: nilam_wid@yahoo.com
}

terkendali, dan teratur dalam memanfaatkan sumber daya yang ada baik berupa uang, material, mesin, metode, lingkungan, sarana dan parasarana yang digunakan untuk mencapai tujuan organisasi.

Organisasi mengalami berbagai macam tantangan dalam menjalankan peran dalam mencapai tujuan. Tantangan yang muncul dapat berasal dari dalam maupun luar organisasi. Organisasi yang mampu 
menghadapi tantangan-tantangan tersebut akan berkembang dan bertahan.

Beberapa faktor yang memengaruhi usaha organisasi untuk berkembang dan bertahan, yaitu: peluang dan kinerja organisasi. Keberhasilan kinerja merupakan salah satu aspek utama yang ingin dicapai, karena meskipun ada peluang namun bila tidak diimbangi oleh kinerja yang baik, maka pertumbuhan organisasi akan terhambat. Oleh sebab itu pada umumnya individu-individu yang tergabung di dalam organisasi diharapkan memiliki kinerja yang tinggi agar tujuan organisasi tersebut tercapai secara efektif.

Dalam dunia bisnis, sangat disadari bahwa kinerja perusahaan sangat ditentukan oleh kinerja individu-individu di dalamnya, namun tidak semua pengelola perusahaan mengerti bagaimana mengelola sumber daya manusia secara tepat sehingga karyawan benar-benar memberikan kontribusi yang efektif bagi perusahaan. Sebagian diantaranya mungkin terpaku pada upaya untuk meningkatkan keuntungan finansial. Banirestu, Suhariyanto, dan Handayani (2003), reporter media bisnis "Swa", menggambarkan bahwa laba bersih cenderung menjadi idaman bagi para pengelola perusahaan, karena laba bersih merupakan suatu indikator kuat keberhasilan dalam mengurus amanat pemangku kepentingan (shareholders).

Orientasi pada pencapaian keuntungan finansial membuat pengelola perusahaan mengabaikan kenyataan adanya kaitan erat antara kinerja perusahaan (yang sering diukur berdasarkan capaian finansial) dengan kinerja individu karyawan. Mereka yang berorientasi pada keuntungan finansial ini tidak segan-segan menggunakan praktik-praktik yang tidak etis: melanggar hak-hak pekerja (SMERU, 2002), merugikan masyarakat dan bahkan meru- sak lingkungan (WALHI, 2007, 2009, 2011). Bila dikaitkan dengan pentingnya kinerja karyawan dalam hubungannya dengan efektifitas perusahaan, maka perusahaan yang dikelola dengan pandangan seperti ini tentu saja cenderung mudah ditinggalkan oleh karyawannya, terutama ditinggalkan oleh orang-orang yang mempunyai kemampuan kinerja yang tinggi, memiliki profesionalisme tinggi, dan berwatak baik. Hal ini dapat terus berulang dan mengakibatkan kemunduran atau terhambatnya perkembangan perusahaan.

Berdasarkan hal tersebut, maka iklim kerja sebuah perusahaan menjadi hal yang penting diperhatikan. Iklim organisasi yang baik akan mendorong kinerja karyawan yang baik pula, demikian juga sebaliknya. Menurut Compton (2005), iklim organisasi yang baik, yang mendorong perkembangan individu dan kinerja yang positif adalah iklim organisasi yang: mendukung perkembangan kompetensi dengan adanya umpan balik; melibatkan hubungan interpersonal yang suportif; mendukung rasa aman; bebas dari evaluasi yang merendahkan; dan memungkinkan akan penghargaan terhadap aspirasi dan perasaan pribadi individu.

Beberapa tahun belakangan muncul kajian yang relatif baru dalam dunia psikologi organisasi yang berfokus pada nilai-nilai spiritual dalam pekerjaan atau yang sering di sebut sebagai spiritualitas di tempat kerja. Spiritualitas di tempat kerja bukanlah agama atau penggantinya, dan bukan tentang menemukan orang yang menerima suatu sistem kepercayaan tertentu. Marques (2001) menjelaskan bahwa spiritualitas adalah melihat ke dalam batin menuju kesadaran akan nilai-nilai universal, sedangkan agama formal melihat keluar menggunakan ritus formal dan kitab suci. Senada dengan pernyataan itu Cacioppe (2000) mengatakan bahwa aga- 
ma formal memiliki orientasi eksternal, sedangkan spiritualitas mencakup seseorang yang memandang ke dalam batinnya dan oleh karenanya dapat dijangkau oleh semua orang, baik yang religius maupun yang tidak. Kajian spiritualitas di tempat kerja yang berlandasakan semangat tersebut, menawarkan kondisi psikologis dalam bekerja yang jika dimiliki dan dikembangkan dalam sebuah organisasi, maka dapat membawa dampak yang positif pada kehidupan individu sendiri maupun organisasi tempat ia bekerja.

Ashmos dan Duchon (2000) mendefinisikan secara sistematis bahwa spiritualitas di tempat kerja merupakan pemahaman diri individu sebagai makhluk spiritual yang jiwanya membutuhkan pemeliharaan di tempat kerja dengan segala nilai yang ada dalam dirinya; mengalami pengalaman akan rasa bertujuan dan bermakna dalam pekerjaannya; serta juga mengalami perasaan saling terhubung dengan orang lain dan komunitas di tempat individu bekerja. Menurut Ashmos dan Duchon (2003);

"Spiritualitas bukan merupakan hal yang baru dalam pengalaman manusia. Dalam semua tradisi-tradisi agama besar pada level tertentu mendorong kehidupan kontemplatif, di mana pencarian makna dan tujuan merupakan hal yang utama dan bahwa hidup dalam harmoni dengan orang lain dipandang sebagai sesuatu yang sangat penting. Dalam kehidupan pribadi, spiritualitas semacam itu wajar berkembang meski harus berhadapan dengan arus nilai-nilai lain yang cenderung memacu perolehan materi. Namun ketika berada dalam dunia kerja, seseorang yang menghidupi spiritualitas seringkali terbentur dengan batasan manajemen dan organisasi klasik yang memandang manajemen sebagai alat impersonal untuk memperoleh tujuan akhir yakni materi dan melakukan fungsi kontrol terhadap karyawan. Konsep birokrasi dari Weber yang berkembang luas penerapannya, jelas menggambarkan hal itu" (hal. 135).

Spiritualitas kerja merupakan salah satu jenis iklim psikologis di tempat kerja. Mengenai hal ini Duchon dan Plowman (2005) menjelaskan sebagai berikut:

"Spiritualitas di tempat kerja merupakan salah satu jenis iklim psikologis di mana orang-orang (pekerja) memandang dirinya memiliki suatu kehidupan internal yang dirawat dengan pekerjaan yang bermakna dan ditempatkan dalam konteks suatu komunitas. Unit kerja yang memiliki tingkat spiritualitas yang tinggi berarti mengalami iklim tersebut, dan dapat diduga bahwa unit kerja tersebut akan mengalami kinerja yang lebih tinggi" (hal. 816).

Menurut Milliman, Czaplewski, dan Ferguson (2003) spiritualitas di tempat kerja mencakup level personal (pekerjaan yang bermakna/meaningful work), level komunitas (perasaan terhubung dengan komunitas/sense of community), dan level organisasi (penegakkan serta pemeliharaan nilai personal dan kesesuaiannya dengan nilai organisasi/alignment of values).

Kajian mengenai spiritualitas di tempat kerja terinspirasi oleh gagasan Maslow (Maslow, Stephens, \& Heil, 1998) mengenai pentingnya makna hidup dalam dunia kerja. Dirks (dalam Widyarini, 2010) mengungkapkan bahwa kajian tentang spiritualitas di tempat kerja mulai gencar di Amerika sejak tahun 1990-an. Berkembangnya minat terhadap spiritualitas kerja di Amerika dapat dilihat dari merebaknya publikasi berupa jurnal cetak maupun online, buku dan konferensi dengan tema spiritualitas di tempat kerja. Namun demikian, di Eropa hal ini kurang mendapat perhatian serius (Krasteva, 2007). Bagai- 
manapun sebagian orang masih meragukan penerapan spiritualitas di tempat kerja, dianggap sebagai hal yang tidak pada tempatnya. Beberapa artikel mengemukakan kritik yang cukup tajam mengenai spiritualitas di tempat kerja, menganggap spiritualitas kerja sebagai upaya memanipulasi secara terorganisir terhadap kepercayaan dan praktik disiplin karyawan, sehingga secara sistematis meningkatkan perilaku pencarian dan pencapaian tujuan-tujuan organisasi (Case \& Gosling, 2010).

Perhatian pada kondisi psikologis individu dalam kajian spiritualitas di tempat kerja bermula dari fenomena mengenai pekerjaan manusia yang lama kelamaan dinilai sebagai rutinitas untuk mencari uang atau insentif lain. Bekerja seolah-olah hanya dilihat sebagai kegiatan yang mekanistik tanpa pemaknaan, padahal manusia pada dasarnya memiliki hasrat untuk hidup bermakna dan mencari identitas diri dari pekerjaan (Maslow, dkk., 1998).

Sejauh ini, berdasarkan kajian mengenai spiritualitas, ditemukan bahwa individu yang menghidupi spirit ini mengalami: kemunculan nilai-nilai terdalam dari individu yang menunjang pekerjaan, selain itu juga memberikan harapan akan adanya pemenuhan diri secara mendalam dan seimbang sehingga mengalami kegembiraan dan bermakna dalam pekerjaannya.

Individu yang menghidupi nilai spiritual dalam pekerjaannya ketika berhubungan dengan orang lain, maka akan melihat dirinya sebagai bagian dari komunitas yang dapat dipercaya, mengalami perkembangan pribadi sebagai bagian dari komunitas di mana mereka merasa dihargai dan didukung. Pema-haman akan spiritualitas di tempat kerja membuat seseorang merasa setara dan memungkinkan mereka hidup dalam lingkungan yang bebas dari rasa takut, sehingga lebih tajam dalam intuisi dan kreativitas, serta rasa kepemilikan akan organisasi tempatnya bernaung.

Penelitian Milliman, Czaplewski, dan Ferguson (2003) pada karyawan magang pada sebuah perusahaan, ditemukan bahwa komponen-komponen spiritualitas di tempat kerja (pekerjaan yang bermakna, perasaan terhubung dengan komunitas, dan penegakan nilai-nilai) dalam diri seseorang berkontribusi secara nyata terhadap komponen-komponen pada konstruk perilaku kerja yang dimiliki individu. Berdasarkan hasil penelitian ini, komponen pekerjaan yang bermakna dan perasaan terhubung dengan komunitas memunculkan komitmen terhadap organisasi dimana individu bernaung, memperkecil intensi individu untuk keluar dari pekerjaan, memunculkan kepuasan kerja intrinsik, memunculkan keterlibatan lebih terhadap pekerjaan, dan meningkatkan self-esteem dalam diri. Dalam penelitian yang sama, komponen penegakan nilai-nilai juga memunculkan kepuasan kerja intrinsik dan memperkecil intensi individu untuk keluar dari pekerjaan. Hasil penelitian lain, oleh Dehaghi, dkk. (2012) menunjukkan bahwa dengan meningkatkan iklim spiritualitas di tempat kerja, komitmen organisasi dan kinerja individu dan organisasi dapat ditingkatkan.

Di Indonesia, penelitian mengenai spiritualitas di tempat kerja belum terlalu banyak ditemukan. Beberapa hasil penelitian yang telah dilakukan menunjukkan konstruk spiritualitas di tempat kerja memiliki kontribusi yang signifikan terhadap perkembangan motivasi intrinsik karyawan terutama komponen penegakkan nilai-nilai (Yogatama, 2012). Motivasi intrinsik sendiri mencakup: rasa senang (interest/enjoyment) ketika melakukan suatu pekerjaan, perasaan serta usaha yang terus meningkat untuk menguasai sebuah 
bidang atau pekerjaan (mastery), otonomi, dan perilaku saling mendukung sesama rekan kerja (relatedness).

Penelitian Widyarini (2011), menemukan bahwa spiritualitas di tempat kerja memiliki kontribusi signifikan terhadap civic virtue. Civic virtue merupakan salah satu dimensi perilaku kewargaorganisasian (organizational citizenship behavior/ OCB) dari lima dimensi yang pernah diusulkan oleh Organ (Organ, Podsakoff, \& MacKenzie, 2006), yaitu altruism, courtesy, sportsmanship, civic virtue, dan conscientiousness. Civic virtue, menunjukkan sejauhmana seseorang memberikan kontribusi terhadap kebijakan-kebijakan dalam organisasi secara bertanggungjawab. Hasil penelitian Widyarini tersebut menunjukkan bahwa civic virtue merupakan prediktor yang sangat kuat untuk kinerja dalam tugas, dan dalam konteks model teorinya secara utuh menunjukkan bahwa perilaku kewargaorganisasian, khususnya civic virtue merupakan mediator antara variabel-variabel level unit kerja yang diteliti (kepemimpinan spiritual, budaya organisasi terbuka, dan iklim spiritualitas kerja) dengan kinerja individu dalam tugas.

Melihat manfaat tersebut, maka penelitian mengenai spiritualitas di tempat kerja perlu terus dikembangkan dalam berbagai macam konteks dan bentuk organisasi; terutama dalam konteks organisasi di Indonesia, konsep ini cukup baru dan sedang berkembang. Penelitian ini adalah salah satu usaha untuk memenuhi hal tersebut.

Penelitian dilaksanakan pada sebuah perusahaan bisnis media nasional. Perusahaan ini dipilih sebagai tempat penelitian karena kesuksesannya dalam mempertahankan visi dan misi sejak tahun 1963 sampai dengan sekarang. Pada saat ini perusahaan sudah menjadi sangat besar dan berkembang pesat di berbagai bidang, serta merambah ke negara lain. Selain dari hal tersebut, perusahaan ini dipilih karena dari segi kepemimpinan yang dilaksanakan dan pengelolaan sumber daya manusia dijalankan berdasarkan nilai-nilai humanis yang sangat relevan dengan indikator yang menunjukkan adanya penerapan spiritualitas di tempat kerja. Berbagai kayawan perusahaan ini mengaku bekerja dengan merasakan suatu spirit bersama mengemban tugas demi kesejahteraan bersama, bahkan demi bangsa. Pimpinan juga memberikan perhatian tinggi agar karyawan tetap profesional dan berwatak baik.

Tujuan dari penelitian ini adalah mengkaji faktor-faktor spiritualitas di tempat kerja dalam konteks organisasi bisnis di Indonesia. Penelitian ini dapat berguna bagi organisasi yang ingin mengembangkan budaya atau iklim organisasi yang mendukung perkembangan personal kehidupan karyawan dan pada akhirnya dengan sendirinya meningkatkan kinerja perusahaan. Dari penelitian ini akan didapatkan faktor yang dianggap penting oleh individu dalam perusahaan mengenai iklim yang mereka rasakan baik dan meningkatkan kualitas hidup karyawan maupun pekerjaan. Diharapkan hal ini dapat mendorong penerapan spiritualitas di tempat kerja di Indonesia dan sekaligus menjawab kritik yang memandang penerapan spiritualitas di tempat kerja sebagai upaya memanipulasi karyawan demi kepentingan organisasi.

\section{Metode}

Subjek penelitian ini adalah 417 karyawan tetap yang bekerja di sebuah perusahaan bisnis yang bergerak di bidang media nasional, terdiri dari berbagai macam latar belakang biografis seperti 
jenis kelamin, usia, tingkat pendidikan, pengalaman, dan etnis.

Penelitian ini termasuk penelitian kuantitatif, yaitu pendekatan yang mengukur variasi sebuah situasi atau fenomena sosial dengan menggunakan data berupa angka atau variabel kuantitatif. Variabel dalam penelitian ini adalah spiritualitas di tempat kerja atau lebih tepatnya iklim spiritual di tempat kerja. Instrumen penelitian yang digunakan adalah kuesioner iklim spiritual di tempat kerja yang diadaptasi berdasarkan elaborasi dari kuesioner Ashmos dan Duchon (2000) serta Milliman (2003). Secara keseluruhan alat ukur spiritualitas di tempat kerja dalam penelitian ini terdiri dari 22 butir pernyataan yang mecakup tiga komponen spiritualitas, yaitu meaningful work, sense of community, alignment of values. Tabel 1 merupakan kisi-kisi alat ukur yang digunakan sebagai data awal penelitian.

Data yang terkumpul kemudian dianalisis menggunakan analisis faktor eksploratori (exploratory factor analysis/ EFA) untuk menemukan kelompok faktorfaktor mengenai iklim spiritual. Adapun syarat yang harus dipenuhi dalam EFA adalah Nilai Kaiser-Meyer-Olkin (KMO) lebih besar dari 0,5 dan nilai Bartlett's Test lebih kecil dari 0,05. Pada tahap pembentukan faktor dilakukan analisis terhadap Initial Eigenvalues hasil analisis faktor yang memiliki nilai satu dan nilai cumulative minimal $50 \%$ pada komponen faktor. Nilai factor loading yang disarankan adalah $\geq 0,5$, masing-masing komponen minimal tiga aitem, dan reliabilitas alpha cronbach data awal $\geq 0,7$ (Garson, 2006; Starkweather \& Herrington, 2012).

Uji validitas dilakukan dengan cara peneliti melakukan pengecekan kesesuaian isi dan makna butir dengan konstruk yang akan diukur. Hal tersebut dilakukan dengan melihat internal consistency pada faktor yang terbentuk dan terhitung dengan sendirinya dari analisis faktor yang dilakukan pada penelitian ini.

\section{H a s i 1}

Sebelum melakukan interpretasi dan memaparkan hasil analisis, peneliti berusaha memenuhi persyaratan untuk dapat melakukan analisis faktor seperti yang sudah disebutkan sebelumnya. Berbagai usaha termasuk mereduksi sejumlah indikator perilaku telah dilakukan dan pada akhirnya berhasil menemukan bentuk set data yang memenuhi persyaratan tersebut. Berikut ini adalah hasil analisis faktor tersebut:

Uji KMO dan Bartlett. Nilai KaiserMeyer-Olkin Measure of Sampling Adequacy pada analisis adalah sebesar 0,917 , yang artinya adalah data set tersebut sangat memadai untuk analisis di langkah selanjutnya karena memiliki korelasi yang baik di antara data-data/indikator perilaku yang ada. Demikian juga dengan Bartlett's Test of Sphericity yang mempunyai nilai 3180.103 dengan nilai signifikansinya sebesar 0,000 juga menunjukkan bahwa data ini layak untuk dianalisis lebih lanjut.

Anti-Image Matrices. Pada penelitian ini, nilai MSA berkisar antara rentang 0,847 - 0,960. Dengan demikian maka indikator dalam penelitian ini dinilai layak untuk analisis faktor. Persyaratan minimal adalah MSA $=0,5$.

Communalities. Ini merupakan nilai yang menunjukkan kontribusi indikator yang menjadi prediktor terhadap faktor yang terbentuk. Communalities pada dasarnya adalah jumlah varian (dalam persentase). Dalam penelitian ini, nilai communalities berkisar antara 0,54-0,765. Semakin besar communalities sebuah indikator perilaku, maka semakin erat hubungannya dengan faktor yang terbentuk. 
Tabel 1

Kisi-kisi alat ukur Spiritualitas di tempat kerja

\begin{tabular}{|c|c|}
\hline Komponen & Indikator Perilaku \\
\hline $\begin{array}{l}\text { Perasaan bermakna } \\
\text { dalam pekerjaan } \\
\text { (Meaningful work) }\end{array}$ & $\begin{array}{l}\text { Merasa nyaman sehingga dapat menggunakan bakat dan talenta } \\
\text { pribadi } \\
\text { Merasakan spirit yang dibangkitkan oleh pekerjaan } \\
\text { Merasa bahwa pekerjaan berhubungan dengan hal yang penting dalam } \\
\text { hidup } \\
\text { Melihat hubungan antara pekerjaan dengan hal-hal yang baik secara } \\
\text { sosial } \\
\text { Memahami makna pribadi (belajar dan berkembang) yang diberikan } \\
\text { oleh pekerjaan } \\
\text { Iklim membuat individu menyukai pekerjaan } \\
\text { Merasakan adanya masa depan yang lebih baik bersama dengan rekan } \\
\text { kerja }\end{array}$ \\
\hline $\begin{array}{l}\text { Perasaan terhubung } \\
\text { dengan komunitas } \\
\text { (sense of community) }\end{array}$ & $\begin{array}{l}\text { Merasa sebagai bagian dari komunitas } \\
\text { Percaya bahwa rekan kerja saling mendukung } \\
\text { Merasa bebas mengekspresikan pendapat } \\
\text { Merasa bahwa karyawan terhubung dengan tujuan bersama dalam } \\
\text { pekerjaan } \\
\text { Percaya bahwa karyawan saling peduli } \\
\text { Merasa sebagai satu keluarga } \\
\text { Merasa sejalan dengan nilai-nilai organisasi }\end{array}$ \\
\hline $\begin{array}{c}\text { Penegakan } \\
\text { nilai-nilai } \\
\text { (alignment of values) }\end{array}$ & $\begin{array}{l}\text { Merasakan bahwa organisasinya peduli pada kaum yang kesusahan } \\
\text { atau tertindas } \\
\text { Merasakan bahwa organisasinya memberi perhatian pada semua } \\
\text { karyawan } \\
\text { Merasakan bahwa organisasinya memilki consciente / hati nurani yang } \\
\text { tertuang dalam tujuan dan pengelolaan organisasi } \\
\text { Merasa tergerak dengan tujuan-tujuan organisasi } \\
\text { Merasa bahwa organisasi peduli terhadap kesehatan karyawan } \\
\text { Merasa terhubung dengan misi organisasi } \\
\text { Merasa bahwa organisasi peduli pada kehidupan spiritual karyawan }\end{array}$ \\
\hline
\end{tabular}

Total Variance Explained. Hasil analisis menunjukkan bahwa varians yang diwakili oleh faktor-faktor yang terbentuk dari penelitian ini adalah sejumlah $64.728 \%$. Sesuai dengan syarat ideal analisis faktor yang telah dijelaskan, pada nilai Total initial eigenvalues jumlah komponen yang memiliki nilai $\geq 1$ berjumlah dua buah. Dengan demikian mengacu pada total initial eigenvalues disarankan terbentuk dua faktor.
Rotasi Faktor. Rotasi faktor yang digunakan dalam penelitian ini adalah metode varimax. Tujuan rotasi faktor varimax adalah berusaha memaksimalkan banyaknya indikator perilaku dengan muatan tinggi (high loading) pada suatu faktor, sehingga memudahkan pembuatan interpretasi mengenai faktor karena indikator perilaku yang masuk dalam faktor tertentu dapat terlihat dengan jelas. Tabel 2 adalah hasil pengelompokan faktor tersebut. 
Tabel 2

Hasil pengelompokan faktor

\begin{tabular}{|c|c|c|}
\hline \multirow{2}{*}{ Indikator Perilaku } & \multicolumn{2}{|c|}{ Faktor } \\
\hline & 1 & 2 \\
\hline Merasa terhubung dengan misi organisasi & .856 & \\
\hline Merasa tergerak dengan tujuan-tujuan organisasi & .839 & \\
\hline Iklim membuat individu menyukai pekerjaan & .708 & \\
\hline Merasakan adanya masa depan yang lebih baik bersama dengan rekan kerja & .698 & \\
\hline $\begin{array}{l}\text { Merasakan bahwa organisasinya memilki consciente / hati nurani yang } \\
\text { tertuang dalam tujuan dan pengelolaan organisasi }\end{array}$ & .657 & \\
\hline Merasa sebagai bagian dari komunitas (kebersamaan dalam komunitas) & .646 & \\
\hline Merasa sejalan dengan nilai-nilai organisasi & .632 & \\
\hline Merasa bebas mengekspresikan pendapat & & .847 \\
\hline Merasa nyaman sehingga dapat menggunakan bakat dan talenta pribadi & & .775 \\
\hline $\begin{array}{l}\text { Memahami makna pribadi (belajar dan berkembang) yang diberikan oleh } \\
\text { pekerjaan }\end{array}$ & & .714 \\
\hline Merasakan bahwa organisasinya memberi perhatian pada semua karyawan & & .676 \\
\hline $\begin{array}{l}\text { Merasa bahwa karyawan terhubung dengan tujuan bersama dalam } \\
\text { pekerjaan }\end{array}$ & & .634 \\
\hline
\end{tabular}

Berdasarkan hasil analisis faktor tersebut, dapat dilihat bahwa terjadi perubahan dari konsep awal, dari tiga faktor menjadi dua faktor saja. Faktor pertama terdiri dari tujuh indikator perilaku dan faktor kedua terdiri dari lima indikator perilaku. Dari indikator yang mengelompok tersebut, peneliti menamai faktor sesuai dengan tema yang mereka miliki. Tema pada faktor pertama adalah seputar kesesuaian individu dengan keadaan, misi, tujuan dan nilai-nilai organisasi. Faktor tersebut dapat dinamakan sebagai 'PERASAAN BERTUJUAN DAN BERMAKNA DALAM PEKERJAAN', digerakkan oleh misi dan nilai-nilai organisasi yang dilandasi hati nurani'. Tema pada faktor kedua adalah mengenai suasana kerja dan perlakuan organisasi terhadap karyawan, yang dapat dinamakan PERASAAN NYAMAN, BEBAS, DAN MENGALAMI PERKEMBANGAN PRIBADI, didukung oleh kepedulian organisasi untuk memper- temukan kepentingan organisasi dengan kepentingan individu, dan memberdayakan karyawan'.

Setelah tahap pembentukkan faktor, hal berikutnya yang perlu dilihat adalah Component Transformation Matrix dan reliabilitas faktor-faktor tersebut. Component Transformation Matrix menunjukkan nilai korelasi faktor sebelum dan setelah rotasi. Pada penelitian ini, korelasi yang didapatkan cukup besar $(0,751)$, sehingga dapat disimpulkan bahwa faktor yang terbentuk telah sesuai dan tepat. Uji reliabilitas menggunakan teknik alpha cronbach juga menunjukkan bahwa secara keseluruhan maupun per-faktor, mereka sama-sama memiliki nilai yang reliabel (lebih besar dari 0,7). Koefisien reliabilitas keseluruhan adalah 0,926; faktor satu sebesar 0,903; dan faktor dua sebesar 0,864 . 
Tabel 3

Penamaan faktor-faktor spiritualitas di tempat kerja

\begin{tabular}{lc}
\hline \multicolumn{1}{c}{ Indikator Perilaku } & Faktor \\
\hline $\begin{array}{l}\text { Merasa terhubung dengan misi organisasi } \\
\text { Merasa tergerak dengan tujuan-tujuan organisasi }\end{array}$ & \\
Iklim membuat individu menyukai pekerjaan & PERASAAN BERTUJUAN \\
$\begin{array}{l}\text { Merasakan adanya masa depan yang lebih baik bersama } \\
\text { dengan rekan kerja }\end{array}$ & $\begin{array}{c}\text { DAN BERMAKNA DALAM } \\
\text { PEKERJAAN: }\end{array}$ \\
$\begin{array}{l}\text { Merasakan bahwa organisasinya memilki conscience / hati } \\
\text { nurani yang tertuang dalam tujuan dan pengelolaan }\end{array}$ & $\begin{array}{c}\text { digerakkan oleh misi dan nilai- } \\
\text { organisasi }\end{array}$ \\
$\begin{array}{l}\text { Merasa sebagai bagian dari komunitas (kebersamaan dalam yang dilandasi } \\
\text { komunitas) }\end{array}$ & hati nurani \\
$\begin{array}{l}\text { Merasa sejalan dengan nilai-nilai organisasi } \\
\text { Merasa bebas mengekspresikan pendapat }\end{array}$ & \\
$\begin{array}{l}\text { Merasa nyaman sehingga dapat menggunakan bakat dan } \\
\text { talenta pribadi }\end{array}$ & PEBAS, DAN MENGALAMI \\
$\begin{array}{l}\text { Memahami makna pribadi (belajar dan berkembang) yang } \\
\text { diberikan oleh pekerjaan }\end{array}$ & PERKEMBANGAN PRIBADI: \\
$\begin{array}{l}\text { Merasakan bahwa organisasinya memberi perhatian pada } \\
\text { semua karyawan }\end{array}$ & didukung oleh kepedulian \\
Merasa bahwa karyawan terhubung dengan tujuan & organisasi untuk \\
bersama dalam pekerjaan & mempertemukan kepentingan \\
& organisasi dengan kepentingan \\
& individu, dan memberdayakan \\
& karyawan
\end{tabular}

\section{Diskusi}

Hasil penelitian mengenai faktorfaktor iklim spiritualitas di tempat kerja ini berbeda dengan faktor yang direkomendasikan oleh Milliman dan kawankawan (2003) maupun Duchon dan Plowman (2003) yang mendasari penyusunan konsepnya. Faktor-faktor yang semula terdiri dari "pekerjaan yang bermakna; rasa komunitas; dan penegakan nilai-nilai" menjadi "Rasa bertujuan dan bermakna dalam pekerjaan, digerakkan oleh misi dan nilai-nilai organisasi yang dilandasi hati nurani" dan "Perasaan nyaman, bebas, dan mengalami perkembangan pribadi, didukung oleh kepedulian organisasi untuk mempertemukan kepentingan organisasi dengan kepentingan individu, dan memberdayakan karyawan".
Berdasarkan hasil tersebut dapat disimpulkan bahwa "Rasa bertujuan dan bermakna dalam pekerjaan (meaningful work)" merupakan hal yang esensial, yang ada dalam konsep awal dan tetap muncul dari hasil analisis faktor. Namun demikian dalam penelitian ini secara khusus nampak bahwa faktor ini terkait erat dengan penegakan visi, misi, dan nilai-nilai organisasi. Di sisi lain, dua faktor lain dalam konsep, yaitu "perasaan terhubung dengan komunitas (sense of community)" dan "penegakan nilai-nilai (aligment of values)" ternyata unsur-unsurnya tersebar ke dalam dua faktor hasil analisis faktor.

Bila dicermati indikator-indikator yang mengumpul dalam Faktor pertama, ada beberapa hal yang penting untuk diperhatikan dalam hal pembentukan iklim spiritual dalam organisasi. Hal 
tersebut adalah: (1) pentingnya kejelasan dan arah pernyataan visi-misi dan nilainilai organisasi sehingga para karyawan dapat menilai secara personal mengenai kecocokan nilai dalam dirinya dengan tujuan/misi/nilai-nilai organisasi. Karyawan yang merasa cocok dengan nilai-nilai dalam organisasi akan tetap tinggal dan menghidupinya (merasa terhubung dan tergerak untuk melakukan sesuatu atas dasar nilai tersebut), dan (2) Pentingnya membangun iklim yang menyenangkan (untuk bekerja sehingga karyawan melihat bahwa organisasi memiliki nilai yang baik sehingga pada akhirnya mereka merasa memiliki masa depan yang baik pula bersama rekan kerja dan organisasi tempat mereka bernaung.

Pada pembentukan iklim yang mengacu pada faktor kedua, hal yang perlu diperhatikan adalah: (1) pentingnya kesadaran bahwa karyawan secara personal memiliki kebutuhan untuk berkembang, belajar, dan mengasah keterampilan. Berdasarkan hal ini maka usaha yang perlu dilakukan adalah membentuk iklim yang memfasilitasi, yaitu: memberi kesempatan perkembangan kompetensi dengan adanya umpan balik; melibatkan hubungan interpersonal yg suportif; mendukung rasa aman; bebas dari evaluasi yang merendahkan; (2) pentingnya kesadaran bahwa setiap individu memiliki kebutuhan untuk berekspresi dan mengemukakan aspirasinya. Iklim yang perlu dibentuk adalah iklim yang memungkinkan penghargaan terhadap aspirasi dan terjaminnya kebebasan untuk berpendapat; dan (3) pentingnya kesadaran akan tujuan bersama. Oleh sebab itu perlu dibentuk iklim yang menyadarkan bahwa para karyawan memiliki tujuan bersama dan untuk mencapainya butuh kerja sama dan kepedulian satu dengan lainnya.
Hasil analisis faktor eksploratori ini menunjukkan bahwa spiritualitas di tempat kerja merupakan hasil dari penerapan suatu nilai-nilai etis di tempat kerja. Hal ini sejalan dengan berbagai temuan mengenai spiritualitas di tempat kerja. Misalnya, Mahadevan (2013) berdasarkan telaah beberapa sumber menyimpulkan bahwa spiritualitas kerja pada dasarnya berarti karyawan mengalami transendensi-diri, makna, dan rasa komunitas di tempat kerja. Fahri (2010) meninjau 140 makalah tentang spiritualitas kerja, dan mengulas temuan-temuan tentang bagaimana spiritualitas mendukung kinerja organisasi. Berdasarkan literatur yang ada ia menyimpulkan adanya tiga perspektif yang berbeda yang diperkenalkan tentang bagaimana spiritualitas bermanfaat bagi karyawan dan mendukung kinerja organisasi: (a) Spiritualitas meningkatkan kesejahteraan dan kualitas hidup karyawan; (b) Spiritualitas memberikan karyawan rasa tujuan dan makna di tempat kerja; dan (c) Spiritualitas memberikan kepada karyawan rasa keterhubungan dan rasa komunitas. Literatur-literatur yang ada memperkenalkan potensi manfaat membawa spiritualitas ke tempat kerja, menyediakan rekomendasi dan saran bagi para praktisi untuk memasukkan spiritualitas positif di organisasi.

Hasil penelitian ini tidak terdapat indikasi praktik non-etis seperti yang dikhawatirkan oleh Kumari (2013). Kumari mengingatkan mengenai kemungkinan penerapan spiritualitas di tempat kerja yang menyimpang. Tidak diragukan bahwa dalam praktik spiritualitas di tempat kerja rentan terjadi pelanggaran, meskipun tidak membantah bahwa kita mungkin menemukan cara baru untuk bekerja dengan satu pertanyaan eksistensial yang penting dalam konteks tempat kerja. Kumari mengingatkan bahwa kita 
harus waspada terhadap perangkap: Untuk membuat orang menjadi spiritual dan sadar akan tanggung jawab sosial mereka, mungkin semakin ketat pada bagian manajemen, dan mendorong mereka terus berjuang untuk mencapai itu sampai seperti tidak bermoral. Sikap bisnis yang tidak sensitif dan sembrono akan memengaruhi reputasinya.

Peringatan dari Kumari tersebut perlu menjadi perhatian para praktisi. Bagaimanapun juga upaya penerapan spiritualitas di tempat kerja oleh pihak manajemen, hanya akan memberikan hasil yang positif apabila tidak terdapat tekanan. Hal ini diperkuat dengan hasil penelitian Sprung, dan kawan-kawan (2012). Berdasarkan sampel dari 854 peserta Survei Sosial Umum (General Social Survey) Sprung, dan kawan-kawan menemukan bahwa spiritualitas di tempat kerja berkaitan dengan hasil-hasil positif dari karyawan kecuali ketika agresi tempat kerja hadir. Dengan adanya agresi di tempat kerja, karyawan yang spiritual cenderung lebih rentan mengalami hasil negatif daripada karyawan yang kurang spiritual.

Untuk memastikan bahwa spiritualitas di tempat kerja yang diteliti merupakan praktik yang etis, di masa yang akan datang, penelitian mengenai hal ini perlu mempertimbangkan model penelitian yang disarankan oleh Heaton dkk. (2004). Artikel mereka yang berjudul "Constructs, methods, and measures for researching spirituality in organizations" menjelaskan bahwa penelitian spirituaitas di organisasi berarti: (1) penelitian subjektif mengenai pengalaman pengembangan pribadi dan transformasi organisasi; dan (2) asesmen objektif mengenai efek spiritualitas sebagai luaran. Penulis mengembangkan model teoritis yang mendukung pengembangan spiritualitas yang memperkaya semua level pikiran yang diindikasikan dengan peningkatan kesehatan, kebahagian, kebijaksanaan, kesuksesan, dan kepenuhan (fulfillment).

\section{Kesimpulan}

Berdasarkan analisis faktor eksploratori yang dilakukan, terbentuk dua buah faktor yang dapat digunakan untuk mengukur iklim spiritual dalam konteks organisasi bisnis di Indonesia. Faktor pertama adalah 'PERASAAN BERTUJUAN DAN BERMAKNA DALAM PEKERJAAN', digerakkan oleh misi dan nilainilai organisasi yang dilandasi hati nurani'. Faktor kedua adalah 'PERASAAN NYAMAN, BEBAS, DAN MENGALAMI PERKEMBANGAN PRIBADI, didukung oleh kepedulian organisasi untuk mempertemukan kepentingan organisasi dengan kepentingan individu, dan memberdayakan karyawan'. Faktor-faktor tersebut berhasil menjelaskan sebesar $64.728 \%$ mengenai konstruk spiritualitas di tempat kerja. Hasil penelitian ini menunjukkan bahwa dalam konteks perusahaan bisnis perhatian terhadap spiritualitas di tempat kerja perlu terus dikembangkan bila organisasi ingin tetap terus bertumbuh dan bertahan dari berbagai tantangan dengan cara yang sehat melalui perhatian kepada kebutuhan spiritual yang telah menjadi kodrat manusia yang harus dipenuhi termasuk dalam pekerjaan.

\section{Saran}

Spiritualitas di tempat kerja merupakan kajian yang relatif baru baru dalam bidang perilaku keorganisasian di Indonesia. Untuk sebuah kajian konsep baru perlu dilakukan penelitian lebih lanjut yang mencakup jenis organisasi atau jumlah sampel yang lebih banyak. Penelitian ini juga bisa diterapkan dan dijajaki di 
organisasi lain selain organisasi bisnis untuk mendapakan gambaran yang lebih menyeluruh tentang spiritualitas kerja dan kaitannya dengan konstruk psikologi lain yang berkaitan dengan pekerjaan (psikologi organisasi). Selain itu, penelitian selanjutnya sebaiknya melengkapi dengan penelitian kualitatif agar mendapat gambaran lebih utuh dan mendalam mengenai konsep spiritualitas di tempat kerja serta nilai dan pemaknaan pekerjaan yang lebih kontekstual, baik dari pengelola organisasi dan karyawan yang tergabung dalam organisasi.

Hasil penelitian ini juga dapat menjadi sebuah kajian yang bermanfaat untuk para pengelola perusahaan, terutama bagian personalia dan pengembangan organisasi. Telah banyak penelitian yang membuktikan bahwa perhatian kepada spiritualitas dan kehidupan karyawan membawa dampak postif kepada organisasi. Penelitian ini dapat berfungsi sebagai pelengkap dan memberikan panduan praktis mengenai faktor-faktor apa saja yang perlu dikembangkan dan penting diperhatikan untuk menuju kepada iklim yang berpihak kepada spiritualitas dan kebutuhan karyawan tersebut, terutama untuk konteks organisasi di Indonesia.

\section{Kepustakaan}

Ashmos, D. P., \& Duchon, D. (2000). Spirituality at work, A conceptualization and measure. Journal of Management Inquiry, 19(2), 134-145.

Ashmos, D. P., \& Duchon, D. (2005). Nurturing the spirit at work: Impact on work unit performance. The Leadership Quarterly, 16, 807-833.

Banirestu, H., Suhariyanto, \& Handayani, T. (2003). Agar EVA oke. Diunduh dari: http://swa.co.id/2003/10/agar-eva-oke/, tanggal 25 Juni 2011.
Cacioppe, R. (2000). Creating Spirit at work, Re-visioning organization development and leadership - Part I. The Leadership \& Organization Development Journal, 21(1), 48-54.

Case, P., \& Gosling, J. (2010) The spiritual organization: critical reflections on the instrumentality of workplace spirituality. Journal of Management, Spirituality and Religion, 7(4), 257-282.

Compton, W. C. (2005). Introduction to positif psychology. Singapore: Thomson Wadsworth.

Crocker, L., \& Algina, J. (1986). Introduction to classical and modern test theory. Orlando: Harcourt Brace Jovanovich College.

Dehaghi, M. R., Goodarzi, M., \& Arazi, Z. K. (2012). The effect of spiritual values on employees' organizational commitment and its models. Procedia Social and Behavioral Sciences, 62, 159 166.

Duchon, D., \& Plowman, A. T. (2005). Nurturing the spirit at work: Impact on work unit performance. The Leadership Quarterly, 16, 807-833.

Fahri, K. (2010). Spirituality and performance in organizations: a literature review. Journal of Business Ethics, 94(1), 89-106.

Ferdinand, A. (2002). Structural equation modeling dalam Penelitian Manajemen. Semarang: Fakultas Ekonomi Universitas Diponegoro.

Garson, G. D. (2006). Factor analysis. Diunduh dari http://www2.chass.ncsu. edu/garson/pa765/factor.htm tanggal 15 November 2013.

Gravetter, J. F., \& Wallnau, L. B. (2004). Statistics for the behavioral sciences $\left(6^{\text {th }}\right.$ ed.). USA: Thomson Learning.

Hackman, J. R., \& Oldham, G. R. (1989). 
Work redesign. In Netmeyer, W. E. \& Gilberg, J. S. (Eds.). Clasics of organizational behavior (p. 328-335). Illinois: The Interstate Printers \& Publishers, Inc.

Heaton, D. P., Schmidt-Wilk, J., \& Travis, F. (2004). Constructs, methods, and measures for researching spirituality in organizations. Journal of Organizational Change Management, 17(1), 62-82.

Krasteva, V. (2007). Spirituality in business. Baltic Management Review, 2 (1), 69-77.

Kumari, N. (2013). Business ethics and corporate social responsibility: A holistic approach. VSRD International Journal of Business and Management Research, 3(3), 97-102.

Mahadevan, B. (2013). Spirituality in business: Sparks from the anvil in conversation with Suresh Hundre, chairman and MD, Polyhydron Pvt. Ltd. IIMB Management Review, 25, 91-103.

Marques, J. (2001). The possible role of human resources in employee motivation (Through the application of spirituality in the workplace). Diunduh dari: http:// www.anglefire.com/id/joanmarques/P R/index.html. tanggal 5 Januari 2006.

Maslow, A. H., Stephens, D. C., \& Heil, G. (1998). Maslow on management. Singapore: John Wiley \& Sons, Inc.

Milliman, J., Czaplewski, A. J., \& Ferguson, J. (2003). Workplace spirituality and employee work attitudes. An exploratory empirical assessment. Journal of Organizational Change Management, 16(4), 426-447.

Organ, D. W., Podsakoff, P. M., \& MacKenzie, S. B. (2006). Organizational citizenship behavior: Its nature, antecedents, and consequences. USA: Sage Publications, Inc.

SMERU (2002). Hubungan industrial di Jabotabek, Bandung, dan Surabaya pada era kebebasan berserikat. Laporan Penelitian, dukungan USAID/PEG. Diunduhdari: http://www.smeru.or.id /report/research/industrialrelation/hu bunganindustri.pdf. tanggal 22 Agustus 2007.

Sprung, J. M., Sliter, M. T., \& Jex, S. M. (2012). Spirituality as a moderator of the relationship between workplace aggression and employee outcomes. Personality and Individual Differences, 53, 930-934.

Starkweather, J., \& Herrington, R. (2012). Research and statistical support: Principal component analysis in SPSS. Diunduh dari:http://www.unt.edu/rss/class/Jon/ SPSS_SC/Module9/M9_PCA/SPSS_M9 _PCA1.htm. tanggal 15 November 2013

WALHI (2007). Kerusakan lingkungan sebagai dampak kebijakan pro modal dan anti rakyat. Kertas posisi dalam rangka peringatan hari lingkungan hidup nasional. No.3/pr/edwss/VI/2007. Diunduh dari: http://www.walhi.or.id /kampanye/psda/070605_lingk_rsk_su msel_kp/. tanggal 1 Agustus 2008,

WALHI (2009). Media releases. Diunduh dari: http://www.walhi.or.id/quickfinder/media. tanggal 17 April 2009.

WALHI (2011, April) Perusakan lingkungan dilakukan korporasi. Mediaindonesia.com. Diunduh dari: http://mediaindonesia.com. tanggal 25 Juni 2011.

Widyarini, N. (2008). Spiritualitas masuk dunia kerja. Diunduh dari: http:// www.kompas.com/read/aml/2008/01/1 0/20074767. tanggal 1 Februari 2010

Widyarini, N. (2010). Kepemimpinan spiritual untuk kejayaan Indonesia: Mengungkap relevansi konsep kepemimpinan spiritual Fry dengan konsep kepemimpinan Nusantara 


\section{SPIRITUALITAS, SPIRITUALITAS DI TEMPAT KERJA}

yang etis dan universal. Jurnal Paramadina Edisi Khusus, 7(2), 333-349.

Widyarini, N. (2011). Perilaku kewargaorganisasian dan kinerja dalam tugas, dengan prediktor kepemimpinan spiritual, iklim spiritualitas kerja, dan budaya organisasi terbuka. (Disertasi tidak dipublikasikan). Fakultas Psikologi Universitas Gadjah Mada, Yogyakarta.
Yogatama, L. A. M. (2012). Pengaruh tiga komponen spiritualitas di tempat kerja (meaningful work, sense of community, dan alignment of values) terhadap motivasi intrinsik pada sales PT. X. (Skripsi tidak dipublikasikan). Fakultas Psikologi Universitas Katolik Indonesia Atma Jaya, Jakarta. 